Research Report

\title{
Sitotoksisitas Ekstrak Kulit Kakao (Theobroma cacao) terhadap Kultur Sel Fibroblas BHK-21
}

\author{
Fajariana Fitriani $^{1}$,Agus Subiwahjudi ${ }^{2}$, Adioro Soetojo ${ }^{2}$, Tamara Yuanita ${ }^{2}$ \\ ${ }^{1}$ Undergraduate Student of Dental Medicine Faculty, Airlangga University, Surabaya - Indonesia \\ ${ }^{2}$ Staff Department of Conservative Dentistry, Dental Medicine Faculty, Airlangga Univeristy, Surabaya \\ - Indonesia
}

\section{ABSTRAK}

Latar Belakang: Irigasi saluran akar merupakan salah satu tahapan penting untuk menunjang keberhasilan perawatan. Sodium hipoklorit $(\mathrm{NaOCl})$ merupakan larutan irigasi utama yang sering digunakan namun memiliki sejumlah kekurangan yakni bersifat toksik jika diirigasi sampai ke jaringan periradikular. Kakao (Theobroma cacao) merupakan tumbuhan suku Sterculiaeae yang kulit buahnya mengandung senyawa alkaloid, flavonoid, tanin, saponin dan terpenoid. Senyawa-senyawa tersebut terbukti dapat menghambat pembentukan biofilm pada bakteri Enterococcus faecalis yang merupakan bakteri paling resisten pada saluran akar. Ekstrak kulit kakao diharapkan dapat menjadi bahan alternatif irigasi saluran akar yang ideal, sehingga perlu dilakukan penelitian mengenai efek sitotoksisitasnya terhadap jaringan. Tujuan: Menentukan konsentrasi dari ekstrak kulit kakao yang memberikan efek sitotoksik pada sel fibroblas $B H K-21$. Metode: Jenis penelitian yang dilakukan adalah eksperimental laboratoris dengan menggunakan kultur sel fibroblas $B H K-21$. Ekstrak kulit kakao diperoleh melalui maserasi menggunakan etanol $70 \%$ dan dilakukan pengenceran dengan konsentrasi 1,56\%, 3,125\%, 6,125\%, 12,5\%, 25\%, 50\%, dan 100\%. Sel BHK-21 dalam microplate 96 well dipaparkan dengan ekstrak kulit kakao. Uji sitotoksisitas menggunakan MTT assay dan absorbansi warna dibaca menggunakan Elisa reader. Nilai absorbansi dihitung dengan rumus sehingga didapatkan hasil akhir berupa persentase kematian sel. Hasil: Peningkatan konsentrasi ekstrak kulit kakao berbanding lurus dengan kenaikan persentase sel fibroblas $B H K-21$ yang mati. Kesimpulan: Konsentrasi minimum ekstrak kulit kakao yang dapat memberikan efek sitotoksik pada sel fibroblas $B H K-21$ adalah $6,25 \%$.

Kata kunci: ekstrak kulit kakao, sitotoksisitas, MTT assay, sel fibroblas BHK-21

Correspondence:Tamara Yuanita, Staff Department of Conservative Dentistry, Dental Medicine Faculty, Airlangga Univeristy, Surabaya - Indonesia,+628155130747.tamara-y@fkg.unair.ac.id

\section{LATAR BELAKANG}

Perawatan saluran akar merupakan salah satu tindakan dari perawatan

endodontik yang bertujuan untuk mengeliminasi serta mencegah bakteri agar tidak masuk lebih dalam ke sistem saluran akar $^{1}$. Perawatan saluran akar memiliki tiga prinsip dasar yang dikenal sebagai "Triad Endodontic" terdiri atas preparasi biomekanik, irigasi dan disinfeksi, serta obturasi . Keseluruhan dari aspek tersebut merupakan suatu kesatuan yang harus dilakukan dengan benar dan apabila terdapat satu tahapan yang salah, maka dapat menggagalkan seluruh sistem perawatan. Tindakan preparasi harus dilakukan dalam keadaan steril untuk mengurangi terjadinya kegagalan perawatan $^{2}$.

Irigasi saluran akar merupakan salah satu tahapan penting untuk menunjang keberhasilan perawatan karena berfungsi untuk menghilangkan debris, membantu menghilangkan smear layer, menetralkan 
flora normal, dan sebagai pelarut jaringan serta pelumas ${ }^{3}$. Salah larutan irigasi yang paling sering digunakan dalam bidang kedokteran gigi adalah sodium hipoklorit $(\mathrm{NaOCl}), \quad$ yang berfungsi untuk membersihkan dan mendisinfeksi saluran akar $^{4}$.

Konsentrasi sodium hipoklorit yang digunakan pada terapi endodontik berkisar antara $0,5 \%$ sampai $5,25 \%$. Mekanisme kerja dari sodium hipoklorit adalah dengan melarutkan jaringan vital dan nekrotik untuk kemudian merusak protein dan mengubanya menjadi asam amino. Sodium hipoklorit telah digunakan secara luas, namun memiliki sejumlah kekurangan, yakni bersifat toksik jika diirigasi sampai ke jaringan periradikular, sehingga menyebabkan rasa sakit, perdarahan, serta pembengkakan atau oedema yang luas 5 . Pada anak-anak, penggunaan sodium hipoklorit sebagai saluran irigasi dapat menyebabkan terjadinya kerusakan pada folikel gigi permanen, jaringan perifer, dan mukosa rongga mulut ${ }^{6}$. Hal tersebut membuat peneliti terus melakukan pengembangan mengenai larutan irigasi alternatif berbahan dasar alami sebagai pengganti sodium hipoklorit. Salah satu

bahan dasar alami yang dapat dimanfaatkan adalah tanaman kakao.

Kakao atau kokoa (Theobroma cacao) merupakan satu-satunya dari 22 jenis marga Theobroma, suku Sterculiaeae yang diusahakan secara komersial ${ }^{7}$. Terbagi dalam tiga kelompok besar, yaitu Criollo, Forastero dan Trinitario. Dalam tata niaga, kakao Criollo termasuk dalam kelompok kakao mulia (fine flavor cocoa). Sedangkan kakao Forastero merupakan kelompok kakao lindak (bulk cocoa) yang mendominasi hampir $95 \%$ produksi kakao dunia ${ }^{8}$.

Berdasarkan penelitian Rachmawaty et al., (2017) melalui analisis fitokimia menggunakan pelarut etanol dan aseton, diketahui bahwa ekstrak kulit buah kakao mengandung senyawa alkaloid, flavonoid, tanin dan saponin ${ }^{9}$. Sedangkan penelitian milik Loppies \& Yumnas (2014) menunjukkan bahwa ekstrak kulit kakao yang dilarutkan dalam etanol dan diuji secara Kromatografi Lapis Tipis (KLT) mengandung senyawa terpenoid, polifenol atau tanin dan flavonoid $^{10}$. Semua senyawa aktif tersebut merupakan antimikroba nabati yang memiliki potensi besar untuk melawan bakteri, jamur, protozoa, dan virus ${ }^{11}$.

Yuanita et al., (2017) dalam penelitiannya menggunakan ekstrak kulit buah kakao yang diencerkan secara bertingkat dari konsentrasi $100 \%$ hingga $0,19 \%$ menyatakan bahwa ekstrak kulit kakao memiliki kemampuan untuk menghambat pembentukan biofilm pada bakteri Enterococcus faecalis yang merupakan bakteri paling resisten pada saluran akar. Konsentrasi hambat minimal biofilm berada pada konsentrasi $3,12 \%^{12}$.

Ekstrak kulit buah kakao yang telah terbukti memiliki aktivitas antibakteri dan 
antifungi diharapkan bisa menjadi alternatif bahan irigasi saluran akar yang ideal. Oleh karena itu, diperlukan suatu uji sitotoksisitas untuk melihat seberapa besar efek toksik dari bahan tersebut.

Uji sitotoksisitas merupakan bagian awal dari evaluasi suatu bahan kedokteran gigi sebelum digunakan pada manusia ${ }^{13}$. Media uji yang paling banyak digunakan adalah sel fibroblas Baby Hamster Kidney21 (BHK-21). Kultur ini banyak digunakan karena memiiki sifat stabil, tidak mengalami mutasi, mudah tumbuh, dan mudah dikultur. Sedangkan metode yang paling sering digunakan adalah dengan metode Microculture Tetrazolium Technique Assay (MTT Assay) karena dapat digunakan untuk mengukur sampel dalam jumlah besar, waktu relatif cepat, sensitif, dan akurat ${ }^{14}$.

Dasar uji enzimatik MTT yaitu dengan melakukan pengukuran terhadap kemampuan sel hidup berdasarkan aktivitas mitokondrianya. Sel yang masih hidup dan metabolismenya aktif, dapat mengubah MTT menjadi produk formazan berwarna ungu. Sedangkan sel yang mati akan kehilangan kemampuan untuk mengubah MTT menjadi formazan ${ }^{15}$.

Hingga saat ini belum ada penelitian lebih lanjut mengenai sitotoksisitas ekstrak kulit kakao (Theobroma cacao) terhadap sel fibroblas $B H K-21$, sehingga perlu dilakukanpenelitianmengenai sitotoksisitas untuk mengetahui efek toksik ekstrak kulit kakao pada sel fibroblas $B H K-21$.

\section{BAHAN DAN METODE}

a. Pembuatan Ekstrak Kulit Kakao ${ }^{16}$

Satu kilogram kulit kakao jenis Forastero yang berasal dari PT. Perkebunan Nusantara XII-Kebun Kaliklatak Banyuwangi dibersihkan, kemudian dipotong tipis dengan ketebalan sekitar 1-2 mm, selanjutnya dikeringkan di udara terbuka selama tiga hari. Kulit kakao yang telah kering digiling hingga menjadi serbuk. Sebanyak 40 gram serbuk kulit kakao dimaserasi dengan menggunakan pelarut dengan cara direndam pada $400 \mathrm{ml}$ etanol $70 \%$ dalam shaker (Shreeji, India) dengan kecepatan 120 rpm secara kontinyu selama 24 jam. Hasil larutan disaring dengan menggunakan kertas saring Whatmann no.41, (GE Healthcare Life Science, USA) sehingga diperoleh maserat. Pelarut (etanol) dalam maserat diuapkan menggunakan rotary vacuum evaporator (Shreeji, India) sampai diperoleh ekstrak dengan bobot konstan.

b. Pengenceran Ekstrak Kulit Kakao ${ }^{17}$

Pengenceran ekstrak kulit kakao dilakukan di Pusat Veteriner Farma Surabaya (PUSVETMA). Ekstrak kulit kakao diencerkan dalam berbagi konsentrasi dengan menggunakan media Eagles (Gibco, USA).

- Kosentrasi 50\% didapatkan dengan mengencerkan 0,50 ml ekstrak kulit kakao 
$100 \%$ dan ditambahkan dengan $0,50 \mathrm{ml}$ media Eagles.

- Kosentrasi 25\% didapatkan dengan mengencerkan 0,25 ml ekstrak kulit kakao $100 \%$ dan ditambahkan dengan $0,75 \mathrm{ml}$ media Eagles.

- Kosentrasi 12,5\% didapatkan dengan mengencerkan $0,125 \mathrm{ml}$ ekstrak kulit kakao $100 \%$ dan ditambahkan dengan $0,875 \mathrm{ml}$ media Eagles.

- Kosentrasi 6,25\% didapatkan dengan mengencerkan $0,0625 \mathrm{ml}$ ekstrak kulit kakao $100 \%$ dan ditambahkan dengan 0,9375 ml media Eagles.

- Kosentrasi 3,125\% didapatkan dengan mengencerkan 0,03125 ml ekstrak kulit kakao $100 \%$ dan ditambahkan dengan 0,96875 ml media Eagles.

- Kosentrasi $1,56 \%$ didapatkan dengan mengencerkan 0,0156 ml ekstrak kulit kakao $100 \%$ dan ditambahkan dengan 0,9844 ml media Eagles.

\section{c. Persiapan Kultur Sel Fibroblas BHK-}

\section{$21^{18,19}$}

Kultur sel induk (seed cells) yang sebelumnya telah dibekukan, dicairkan dalam akuades steril suhu $37^{\circ} \mathrm{C}$. Kemudian diputar dengan centrifuge $1500 \mathrm{rpm}$ selama 15 menit. Di dalam laminar flow (Clemco, Australia), supernatan yang ada dibuang sehingga tersisa endapan sel di dasar. Endapan sel tersebut kemudian diambil dan disuspensikan dengan media
Eagles dan Fetal Bovine Serum 10\% (SERANA®, Jerman). Media Eagles sebanyak $36 \mathrm{ml}$ ditambahkan ke dalam botol Roux (Duran®, Jerman) yang berisi serum $4 \mathrm{ml}$. Endapan sel yang telah disuspensikan, ditanam dalam botol Roux steril, kemudian diinkubasi dalam incubator (Memmert, Jerman) pada suhu $37^{\mathrm{O}} \mathrm{C}$, sampai sel monolayer terbentuk.

Sel fibroblas diambil dari kultur sel $B H K$ 21 dalam bentuk cell-line ditanam dalam botol Roux. Media pada botol Roux yang berisi sel fibroblas $B H K-21$ dibuang dan dicuci dengan Phospate Buffer Saline (PBS) (Sigma-Aldrich, USA) 15 ml sebanyak 3-5 kali. Botol Roux diisi dengan trypsin versene (Lonza ${ }^{\mathrm{TM}}$, USA) $1 \mathrm{ml}$. Sel-sel dalam botol tersebut akan terlihat menggerombol kemudian dihomogenisasikan dengan media Eagles sebanyak $10 \mathrm{ml}$. Sel yang telah homogen dimasukkan ke dalam microplate 96 well (TPP®, Swiss) dengan kepadatan $2 \times 10^{5} \mathrm{sel} / \mathrm{ml}$ sebanyak $50 \mu \mathrm{l}$ dan diinkubasi selama 24 jam.

\section{d. Tahapan Perlakuan ${ }^{18,19}$}

Microplate yang berisi sel fibroblas diamati dibawah mikroskop cahaya (Nikon ECLIPSE TE2000-U, Jepang) untuk melihat apakah sel yang ditanam telah cukup banyak untuk dilakukan perlakuan. Sel fibroblas yang sudah didistribusikan dalam sumuran dibagi menjadi 9 kelompok perlakuan, yaitu kelompok I sebagai kontrol negatif berisi media, kelompok

II sebagai kontrol positif yang berisi kultur sel fibroblas, kelompok III - IX sebagai kelompok 
penelitian yang berisi kultur sel fibroblas yang dipaparkan ekstrak kulit kakao dengan konsentrasi $1,56 \%, 3,125 \%$, $6,125 \%, 12,5 \%, 25 \%, 50 \%$, dan $100 \%$ dimana masing-masing sumuran berisi 25 $\mu \mathrm{l}$

Setiap perlakuan memiliki 7 replikasi yang ditanam dalam well. Selanjutnya microplate diinkubasi selama 24 jam pada suhu $37^{\circ} \mathrm{C}$

\section{e. Pengamatan dan Pembacaan Hasil Perlakuan $^{18,19}$}

Media dan ekstrak kulit kakao yang berada di dalam microplate dibuang kemudian dicuci dengan PBS. Garam MTT (SIGMA, USA) dilarutkan dalam $P B S 5$ $\mathrm{mg} / \mathrm{ml}$, kemudian di teteskan ke setiap well sebanyak $10 \mu \mathrm{l}$. Kemudian diinkubasi kembali selama 2-4 jam pada suhu $37^{\circ} \mathrm{C}$.

Dimethylsulfoxide (DMSO) (SigmaAldrich, USA) ditambahkan sebanyak 50 $\mu \mathrm{l}$ ke setiap well dan digetarkan dengan alat shaker selama 5 menit hingga kristal formazan terlarut. Pembacaan nilai densitas optik formazan dengan Elisa reader (Thermo Fisher Scientific, USA) pada panjang gelombang $620 \mathrm{~nm}$. Semakin pekat warna, semakin tinggi nilai absorbansinya dan semakin banyak jumlah sel fibroblas yang hidup. Sel fibroblas yang hidup akan menjadi warna ungu, sedangkan sel yang mati tidak terbentuk warna ungu.
Sel yang mati kemudian dihitung persentasenya dengan mengunakan rumus ${ }^{18}$ : $\%$ Sel hidup $=\frac{\text { OD perlakuan }- \text { OD media }}{\text { OD kontrol sel }- \text { OD media }}$ $\%$ Sel mati $=100 \%-\%$ sel hidup

Hasil penghitungan didasarkan pada nilai IC50. IC50 ekstrak kulit kakao adalah konsentrasi dari ekstrak yang menghambat pertumbuhan sel fibroblas sebesar $50 \%$ dari kontrol sel yang diperoleh dari nilai rerata persentase kehidupan sel.

Jika sel yang mati $>50 \%$ artinya ekstrak kakao bersifat toksik. Jika sel yang mati $<50 \%$ artinya ekstrak kakao bersifat tidak toksik ${ }^{20}$.

\section{HASIL}

Hasil pengamatan mengenai sitotoksisitas ekstrak kulit kakao (Theobroma cacao) dengan pengenceran pada konsentrasi $1,56 \%, 3,125 \%$, $6,125 \%, 12,5 \%, 25 \%, 50 \%$, dan $100 \%$ terhadap kultur sel fibroblas $B H K-21$ yang dilakukan dengan menggunakan metode MTT Assay dan dibaca dengan alat ELISA reader dapat dilihat pada tabel 1. 
Tabel 1. Nilai rata-rata optical density, persentase sel hidup, dan persentase sel mati pada setiap kelompok perlakuan

\begin{tabular}{|c|c|c|c|c|}
\hline $\begin{array}{c}\text { Kelompok } \\
\text { Perlakuan }\end{array}$ & $x \pm$ SD & $\begin{array}{c}\% \text { Sel } \\
\text { Hidup }\end{array}$ & $\begin{array}{l}\% \text { Sel } \\
\text { Mati }\end{array}$ & $\mathrm{N}$ \\
\hline $\begin{array}{c}\text { (1) Kontrol } \\
\text { sel Kontrol } \\
\text { media }\end{array}$ & $0,07 \pm 0,032$ & $0 \%$ & $0 \%$ & 7 \\
\hline $\begin{array}{c}\text { (3) Ekstrak } \\
1,56 \%\end{array}$ & $0,45 \pm 0,015$ & $71,7 \%$ & $28,3 \%$ & 7 \\
\hline $\begin{array}{c}\text { (4) Ekstrak } \\
3,125 \%\end{array}$ & $0,42 \pm 0,020$ & $66,4 \%$ & $33,6 \%$ & 7 \\
\hline $\begin{array}{c}\text { (5) Ekstrak } \\
6,25 \%\end{array}$ & $0,20 \pm 0,016$ & $24,5 \%$ & $75,5 \%$ & 7 \\
\hline $\begin{array}{c}\text { (6) Ekstrak } \\
12,5 \%\end{array}$ & $0,22+0,076$ & $28,3 \%$ & $71,7 \%$ & 7 \\
\hline $\begin{array}{c}\text { (7) Ekstrak } \\
25 \%\end{array}$ & $0,18 \pm 0,066$ & $20,8 \%$ & $79,2 \%$ & 7 \\
\hline $\begin{array}{c}\text { (8) Ekstrak } \\
50 \%\end{array}$ & $0,17 \pm 0,050$ & $18,9 \%$ & $81,1 \%$ & 7 \\
\hline $\begin{array}{c}(9) \text { Ekstrak } \\
100 \%\end{array}$ & $0,120,081$ & $9,4 \%$ & $90,6 \%$ & 7 \\
\hline
\end{tabular}

Keterangan :

$\bar{x} \quad$ : Nilai rata-rata optical density

SD : Standar deviasi/simpangan baku

$\mathrm{N}$ :Jumlah kelompok tiap perlakuan

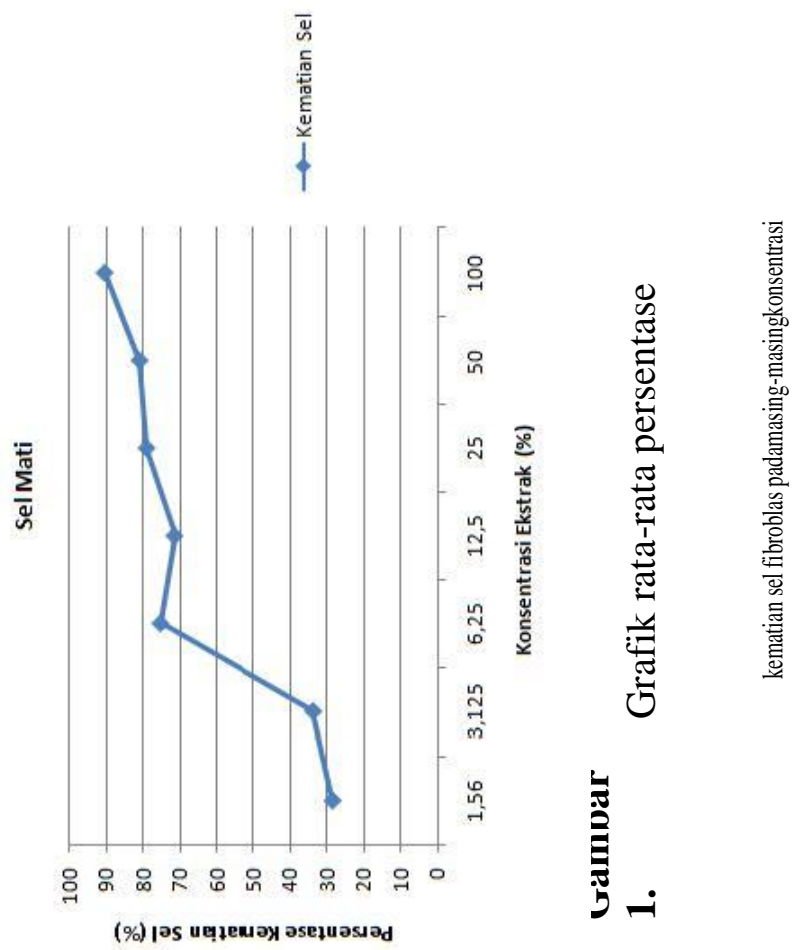

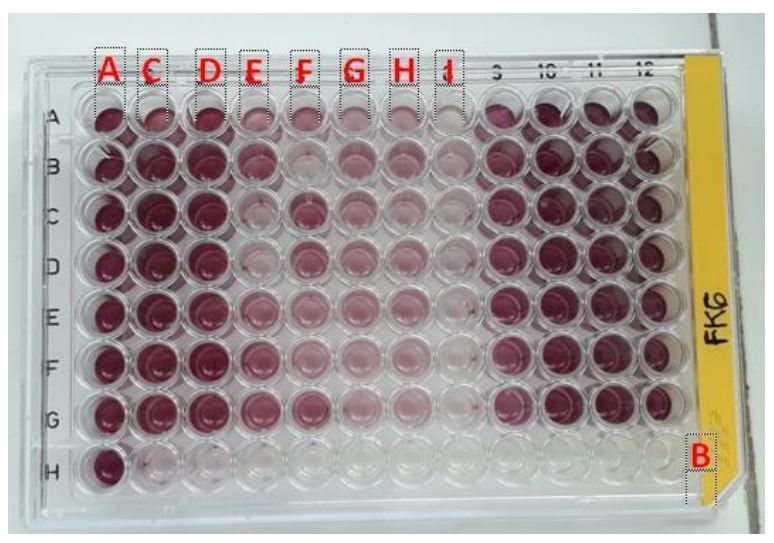

Gambar 2. Hasil pada microplate setelah perlakuan

Keterangan

A: Kontrol sel

B: Kontrol media

C: Perlakuan ekstrak konsentrasi $1,56 \%$

D: Perlakuan ekstrak konsentrasi 3,125\%

E: Perlakuan ekstrak konsentrasi 6,25\%

F: Perlakuan ekstrak konsentrasi 12,5\%

G: Perlakuan ekstrak konsentrasi $25 \%$

H: Perlakuan ekstrak konsentrasi 50\%

I: Perlakuan ekstrak konsentrasi $100 \%$

Berdasarkan data tabel 1 dan gambar grafik 1 semakin tinggi konsentrasi ekstrak maka nilai optical density semakin rendah. Optical density yang rendah menunjukkan tingkat sel hidup yang rendah (sel mati tinggi). Dari gambar 2 juga dapat diketahui bahwa intensitas warna formazan dari sumuran C (konsentrasi 1,56\%) hingga I (konsentrasi 100\%) mengalami penurunan. Intensitas atau kepekatan warna formazan berbanding lurus dengan jumlah sel hidup.

\section{Analisis Data}

Pada data hasil pengukuran optical density menggunakan Elisa reader, dilakukan uji normalitas menggunakan uji KolmogorovSmirnov untuk melihat apakah data yang didapat berdistribusi normal. Data dikatakan 
berdistribusi normal apabila $\mathrm{p}>0,05$. Pada masing-masing kelompok perlakuan diperoleh nilai $\mathrm{p}>0,05$, artinya data yang didapatkan berdistribusi normal. Kemudian dilanjutkan dengan Levene's test untuk mengetahui homogenitas data sebagai syarat uji signifikansi menggunakan ANOVA. Diperoleh hasil $p=0,000$ $(\mathrm{p}<0,05)$ yang menunjukkan data bersifat tidak homogen. Oleh karena itu, uji signifikansi dilakukan menggunakan uji non parametrik melalui analisis Kruskall Wallis test dan didapatkan hasil $\mathrm{p}=0,000$ $(\mathrm{p}<0,05)$ yang menunjukkan adanya perbedaan yang signifikan pada kelompok perlakuan. Selanjutnya untuk mengetahui adanya perbedaan kemaknaan antar perlakuan terhadap kelompok kontrol, maka digunakan uji Post-Hoc comparison test menggunakan metode Tukey HSD.

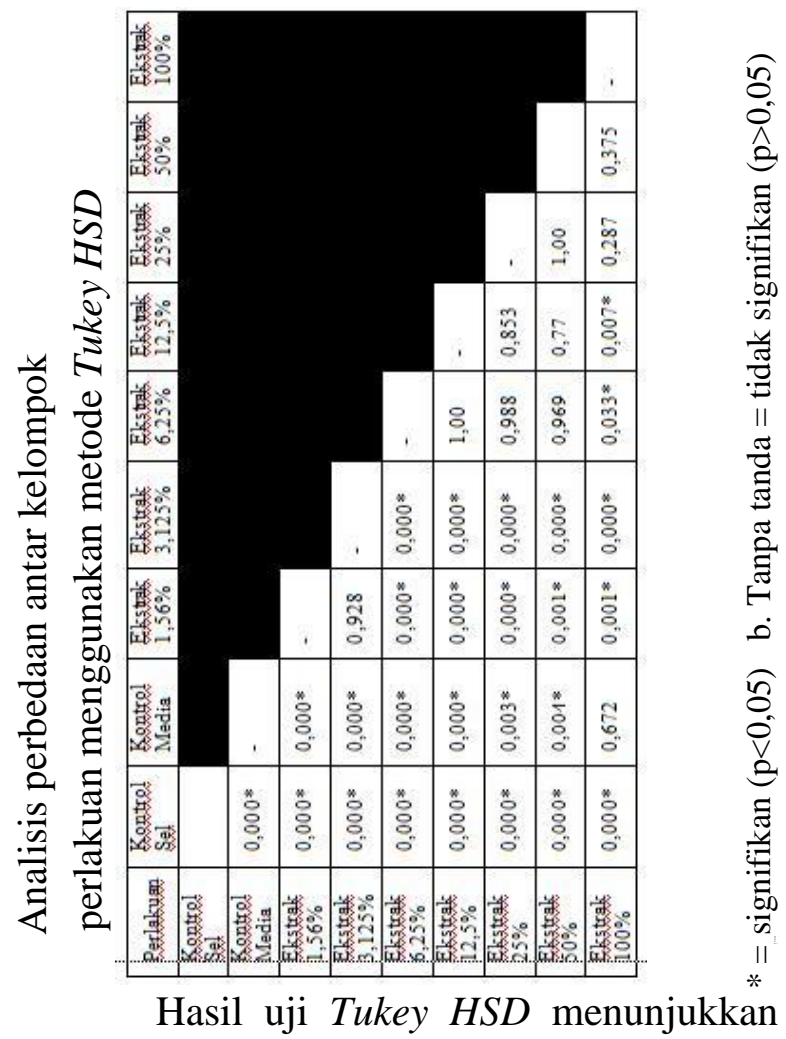

bahwa terdapat perbedaan bermakna antara kelompok kontrol sel dengan semua kelompok perlakuan. Pada konsentrasi 1,56\% didapatkan perbedaan bermakna dengan semua kelompok perlakuan kecuali terhadap konsentrasi 3,125\%. Pada konsentrasi 6,25\% tidak didapatkan perbedaan bermakna dengan konsentrasi $12,5 \%$, $25 \%$ dan 50\%. Pada konsentrasi $25 \%$ tidak didapatkan perbedaan bermakna dengan konsentrasi 50\% dan 100\%. Pada konsentrasi $50 \%$ tidak didapatkan perbedaan bermakna dengan konsentrasi 100\%. Berdasarkan hasil uji tersebut, diketahui ekstrak kulit kakao konsentrasi $6,25 \%, 12,5 \%, 25 \%, 50 \%$, dan $100 \%$ memiliki efek sitotoksik terhadap sel BHK-21.

\section{DISKUSI}

Uji sitotoksisitas merupakan bagian awal dari evaluasi suatu bahan kedokteran gigi sebelum digunakan pada manusia ${ }^{13}$. Metode yang paling sering digunakan adalah Microculture Tetrazolium Technique Assay (MTT Assay) dengan menggunakan pereaksi MTT 3-(4,5-dimethylthiazol-2-yl) 2,5-diphenyl tetrazolium bromide ${ }^{14}$.

Metode $M T T$ didasarkan pada pengukuran terhadap aktivitas mitokondria sel hidup. Sel yang masih hidup dan metabolismenya aktif, dapat mengubah garam MTT yang semula berwarna kuning menjadi produk formazan berwarna ungu melalui reaksi reduksi ${ }^{15,21}$.

Intensitas warna dari kristal formazan dalam microplate 96 well kemudian dibaca 
menggunakan Elisa reader. Absorbansi yang dihasilkan akan sebanding dengan jumlah sel yang hidup. Semakin pekat warna yang ditunjukkan, maka semakin tinggi nilai absorbansinya dan semakin banyak jumlah sel yang hidup $^{22}$.

Metode MTT Assay memerlukan inkubasi reagen dengan kultur sel hidup ${ }^{15}$. Kultur sel yang paling banyak digunakan adalah sel fibroblas Baby Hamster Kidney21 (BHK-21) yang berasal dari ginjal bayi hamster. Sel ini paling banyak digunakan untuk pengujian terhadap tingkat sitotoksisitas suatu material kedokteran gigi dikarenakan memiliki bentuk dan kemampuan yang mirip dengan fibroblas manusia dalam memproduksi growth factor serta memiliki karakteristik mudah dikultur, lebih stabil, lebih sensitif, dan sulit untuk mengalami mutasi jika dibandingkan dengan sel fibroblas $\operatorname{manusia}^{23,22,24,14}$. Pada penelitian ini kultur sel fibroblas diperoleh dari Laboratorium Peningkatan Mutu dan Pengembangan

Produksi Pusat Veteriner Farma

(PUSVETMA) Surabaya.

Kulit kakao didapatkan dari PT. Perkebunan Nusantara XII-Kebun Kaliklatak Banyuwangi berjenis Forastero. Pembuatan ekstrak dan uji fitokimia dilakukan di Balai Penelitian dan Konsultasi Industri (BPKI) Surabaya untuk mengetahui isi kandungan senyawa aktif di dalam ekstrak kulit kakao. Pada hasil uji fitokimia didapatkan senyawa aktif berupa alkaloid sebanyak 5,06\%, flavonoid 3,91\%, tanin $6,11 \%$, saponin $4,05 \%$ dan terpenoid 2,94\% yang dapat berpengaruh pada kematian sel fibroblas.

Alkaloid merupakan senyawa aktif hasil metabolisme sekunder yang terkandung dalam tumbuh-tumbuhan termasuk pada kulit kakao. Efek sitotoksik yang dihasilkan oleh alkaloid dapat menyebabkan terjadinya kebocoran pada membran sel fibroblas $B H K-21$. Alkaloid juga dapat mempengaruhi DNA sel, yakni dengan cara menyisipkan agen interkalasi ke dalam susunan basa di dalam DNA heliks ganda sehingga menyebabkan terjadinya pergeseran kerangka baca dan mengakibatkan terganggunya proses replikasi, perbaikan, serta topoimerase yang berakibat pada apoptosis sel $^{25}$.

Flavonoid merupakan kelompok metabolit sekunder yang banyak ditemukan pada tanaman. Pada konsentrasi yang relatif tinggi, flavonoid bersifat prooksidan karena dapat memicu pembentukan ROS sehingga menimbulkan efek toksik pada sel. Mekanisme kerja dari flavonoid yakni dengan menginaktivasi sel, menghambat proliferasi sel, menghambat peroksidasi lipid, inaktivasi radikal oksigen dan inaktivasi oksidasi DNA yang selanjutnya membuat sel mengalami Sedangkan pada konsentrasi rendah,flavonoid bersifat sebagai antioksidan ${ }^{27}$.

Mekanisme kerja dari flavonoid yakni dengan menangkap radikal bebas 
sehingga mencegah oksidasi sel dan denaturasi protein $^{28,29}$.

Tanin merupakan senyawa aktif metabolit sekunder turunan polifenol. Pemberian tanin dalam konsentrasi tinggi dapat menyebabkan terjadinya genotoksik $^{30}$. Ikatan antar senyawa polar pada tanin dengan lipoprotein sel dapat menyebabkan terjadinya penimbunan

senyawa dan pemecahan lemak. Akibatnya, permeabilitas sel fibroblas menjadi terganggu sehingga sel menjadi nekrosis ${ }^{31}$.

Saponin merupakan kelompok glikosida yang banyak ditemukan pada tanaman, termasuk kulit buah kakao. Dalam senyawa saponin, terdapat molekul ampifatik (mengandung regio hidrofilik dan hidrofobik) yang dapat melarutan protein membran. Ketika ujung hidrofobik saponin berikatan dengan regio hidrofobik protein membran sel, akan menyebabkan pergeseran pada sebagian besar unsur lipid yang terikat. Sedangkan ujung hidrofilik saponin yang merupakan ujung bebas akan membawa protein ke dalam larutan sebagai kompleks deterjen-protein. Akibatnya membran sel akan pecah dan mengalami

lisis, kemudian menyebabkan sel mengalami nekrosis ${ }^{31}$. Saponin juga memiliki kemampuan untuk menginduksi apoptosis pada kultur sel fibroblas ${ }^{32}$.

Terpenoid merupakan senyaawa hidrokarbon alami yang dapat ditemui pada tumbuhan. Senyawa ini dapat berinteraksi dengan protein membran dan biomembran yang kemudian dapat menyebabkan ketidakstabilan ion dan metabolit dalam sel. Ketidakstabilan antara ion dan metabolit sel akan menyebabkan $\operatorname{apoptosis}^{33}$.

Hasil uji statistik pada data penelitian menunjukkan bahwa data berdistribusi normal namun memiliki variasi yang tidak homogen, sehingga analisis statistik selanjutnya dilakukan dengan uji non parametrik melalui uji Kruskall Wallis dan didapatkan hasil bahwa terdapat perbedaan yang signifikan antara jumlah sel yang hidup dari kelompok perlakuan.

Hasil penelitian menunjukkan bahwa semakin tinggi konsentrasi ekstrak, nilai absorbansi yang didapatkan semakin rendah. Hal ini menandakan adanya penurunan jumlah sel hidup atau peningkatan jumlah sel fibroblas $B H K-21$ yang mati seiring dengan peningkatan konsentrasi ekstrak kulit kakao. Pada konsentrasi $1,56 \%$ dan $3,125 \%$ didapatkan jumlah rata-rata sel mati kurang dari 50\% sehingga dapat dikatakan bahwa pada konsentrasi tersebut ekstrak kulit kakao bersifat tidak toksik. Hal ini dapat dikarenakan adanya aktivitas flavonoid sebagai zat antioksidan yang memberikan efek aman terhadap sel fibroblas, sehinga membuat sel fibroblas menjadi tetap hidup (viabel). Sedangkan, pada konsentrasi $6,25 \%, 12,5 \%, 25 \%, 50 \%$ dan $100 \%$ jumlah rata-rata sel mati lebih dari $50 \%$ sehingga dapat dikatakan bahwa pada konsentrasi ini ekstrak kulit kakao bersifat 
toksik, yang menandakan bahwa efek antioksidan senyawa flavonoid mulai berkurang. Adanya kenaikan konsentrasi pada ekstrak kulit kakao kemudian mengubah sifat flavonoid menjadi prooksidan. Flavonoid, alkaloid, saponin, tanin dan terpenoid kemudian secara bersama-sama mempengaruhi sel fibroblas dengan mengakibatkan apoptosis dan nekrosis pada sel.

Secara keseluruhan penghitungan persentase jumlah sel fibroblas $B H K-21$ yang mati setelah dipaparkan ekstrak kulit kakao (Theobroma cacao) dengan konsentrasi $1,56 \%, \quad 3,125 \%, 6,125 \%$, $12,5 \%, 25 \%, 50 \%$, dan $100 \%$ secara berurutan adalah 28,3\%, 33,6\%, 75,5\%, $71,7 \%, \quad 79,2 \%, \quad 81,1 \%$, dan $90,6 \%$. Berdasarkan parameter $\mathrm{IC}_{50}$, ekstrak kulit kakao dengan konsentrasi 6,25\%, 12,5\%, $25 \%$, 50\%, dan $100 \%$ termasuk dalam kategori toksik karena persentase sel yang mati lebih dari 50\%, sedangkan konsentrasi $1,56 \%$ dan $3,125 \%$ bersifat tidak toksik karena persentase sel yang mati kurang dari $50 \%$.

Pada penelitian ini didapatkan data bahwa pengaruh penambahan konsentrasi ekstrak kulit kakao berbanding lurus dengan peningkatan jumlah sel fibroblas BHK-21 yang mati. Namun belum diketahui, apakah ekstrak kulit kakao juga memberikan efek dengan pola yang sama terhadap sel fibroblas yang berasal dari rongga mulut. Data penelitian juga menunjukkan bahwa pada konsentrasi 6,25\% ekstrak kulit kakao memberikan efek sitotoksik, sedangkan pada konsentrasi 3,125\% bersifat terapetik. Hasil uji signifikansi antar kelompok menunjukkan bahwa terdapat perbedaan bermakna antara konsentrasi $6,25 \%$ dan $3,125 \%$. Namun, belum diketahui secara pasti bagaimana efek ekstrak kulit kakao pada rentang antara konsentrasi 6,25\% dan 3,125\% terhadap sel fibroblas $B H K-21$. Maka dari itu, perlu dilakukan penelitian lebih lanjut mengenai sitotoksisitas ekstrak kulit kakao terhadap kultur sel fibroblas yang berasal dari rongga mulut manusia dan pengaruh ekstrak kulit kakao pada konsentrasi antara 3,125\% dan $6,25 \%$.

\section{REFERENCES}

1. Gutmann, J. L., \& Regan, J. D. Preparation of the Root Canal System. In: Ford T. R. P. Harty's Endodontics in Clinical Practice. $5^{\text {th }}$ Ed. Inggris: Elsevier. 2004: 77.

2. Shahani \& Reddy, S. Comparison of Antimicrobial Substantivity of Root Canal Irrigants in Instrumented Root Canals up to $72 \mathrm{~h}$ : an in vitro study. Journal of the Indian Society of Pedodontics \& Preventive Denstistry. 2011; 29: 28-33

3. Gusiyska, A. Effective Root Canal Irrigation - A Key Factor of endodontic Treatment. International Journal of Recent Scirntific Research. 2016; 10(8): 34003419.

4. Haapasalo, M., Shen, Y., Wang, Z. \& Gao, Y. Irrigation in Endodontics. British Dental Journal. 2014; 216(6): 299-303.

5. Lam, T. S. K., Wong, O. F. \& Tang, S. Y. H. A Case Report of Sodium Hypochlorite. Hong Kong Journal of Emergency Medicine. 2010; 17(2): 174- 
175.

6. Chaugule, V. B., Panse, A. M., \& Gawali, P. M. Adverse Reaction of Sodium Hypochlorite during Endodontic Treatment of Primary Teeth. International Journal of Clinical Pediatric Dentistry. 2015; 8(2): 153-156

7. Karmawati, I., Mahmud, Z., Syakir, M., Munarso, S. J., Ardana, I. K., \& Rubiyo. Budidaya dan Pascapanen Kakao. Pusat Penelitian dan Pengembangan Perkebunan. 2010: 112.

8. Rubiyo. Inovasi Teknologi Perbaikan Bahan Tanam Kakao di Indonesia. Buletin RISTRI. 2013; 4(3): 199-214.

9. Rachmawaty., Mu'nisa, A., \& Hasri. Analisis Fitokimia Ekstrak Kulit Buah Kakao (Theobroma cacao L.) sebagai Kandidat Antimikroba. 2017: 667670.

10. Loppies, J. E., \& Yumnas, M. Ekstraksi Komponen Aktif Kulit Buah Kakao dan Pemanfaatannya sebagai Bahan Pengawet Alamai pada Produk Makanan. Jurnal Industri Hasil Perkebunan. 2014; 9(2): 59-67.

11. Chandra, H., Parul, B., Archana, Y., Babita, P., Abhay, P. M., \& Amant, R. N. Antimicobial Resistance and The Alternative Resources with Special Emphasis of Plant-Based Animicrobials. Journal of Plants. 2017; 6(16): 1-11.

12. Yuanita, T., Putri, D. A., Rukmo, M., Zubaidah, N., Wahjuningrum, D. A., $\&$ Kunarti, S. Antibiofilm Power of Cocoa Bean Pod Husk Extract

(Theobroma cacao) Against Enterococcus faecalis Bacteria (In Vitro). International Medical Device and Technology Conference 2017. 2017: 129-131.

13. Yuliati, A. Viabilitas Sel Fibroblas BHK-21 pada Permukaan Resin Akrilik Rapid Heat Cured. Majalah Kedokteran Gigi (Dent. J). 2005; 38(2): 68-72.

14. Khoswanto, C. Uji Sitotoksisitas Dentin Kondisioner Asam Sitrat 50\%
Menggunakan MTT Assay. Dental Journal. 2008; 41: 103-106.

15. Riss, T., Moravec, R., Niles, A., Duellman, S., Benik, H., Worzella, T., \& Minor, L. Cell Viability Assay. Assay Guidance Manual. 2016: 1-4.

16. Mulyatni, A. S., Budiani, A., \& Taniwiryono, D. Aktivitas Antibakteri Ekstrak Kulit Buah Kakao (Theobroma cacao L.) Terhadap Escherichia coli, Bacillus subtillis, dan Staphylococcus aureus. 2012: 77-84.

17. Sulaiman, A. Y., Astuti, P., \& Shita, A. D. P. Uji Antibakteri Ekstrak Daun Kersen (Muntingia Calabura L.) Terhadap Koloni Streptococcus viridians. Indonesian Journal for Health Sciences. 2017; 1(2): 16.

18. Freshney, R. I. Culture of Animal Cell: A Manual of Basic Technique and Specialized. $6^{\text {th }}$ ed. New York: Wiley Liss Inc. 2010: 108, 243.

19. Meizarini, Asti. Perbedaan Konsentrasi

Bahan Pemutih Gigi Terhadap Sitotoksisitas Menggunakan Assay MTT. Jurnal Penelitian Media Eksakta. 2009; 8(1): 9-10.

20. Nalbantsoy, A., Karabay, Y. N. U., Sayim, F., Deliloglu, G., Gocmen, B., Arikan, H., \& Yildiz, M. Determination of in vivo Toxicity and in vitro Cytotoxicity of Venom from the Cypriot Blunt-Nosed Viper Macrovipera lebetina lebetina and Antivenom Production. The Journal of Venomous Animals and Toxins including Tropical Diseases. 2012; 18(2): 208-216.

21. Bahuguna, A., Khan, I., Bajpai, V. K., \& Kang, S. C.. MTT Assay to Evaluate the Cytotoxic Potential of a Drug. Bangladesh J Pharmacol. 2017; 12: 115-118.

22. Emilda, Y., Budiprmana E., \& Kuntari, S. Uji Sitotoksisitas Ekstrak Bawang Putih (Allium sativum) Terhadap Kultur Sel Fibroblas. Dental Journal. 2014; 47(4): 215-219.

23. Dewi, T. P. Efek Sitotoksik Tetrahydrozoline Hcl Terhadap Viabilitas Sel Fibroblas. Interdental Jurnal Kedokteran Gigi. 2007; 5(1).

24. Holland, G. R., \& Torabinejad, M. The Dental Pulp and Periradicular Tissues. In: 
Walton, R. E, Torabinejad, M. Endodontics Principles and Practice. $4^{\text {th }}$ Ed. Missouri: Elsevier. 2009: 263.

25. Fattorusso, E., \& Scafati, O. T..

Modern Alkaloids Structure, Isolation, Synthesis and Biology. Jerman: Wiley-VCH. 2008: 4, 17.

26. Chahar, M. K., Sharma, N., Dobhal, M. P., \& Joshi, Y. C. Flavonoids : A versatile source of anticancer drugs. Pharmacogn Rev. 2011; 5(9): 1-12.

27. Matsuo, M., Sasaki, N., Saga, K., \&

Kaneko, T. Cytotoxicity of Flavonoids Toward Cultured Normal Human Cells. Biol Pharm Bulletin. 2005; 28(2): 253-258.

28. Simanjuntak, K. Peran Antioksidan Flavonoid dalam Meningkatkan Kesehatan. Bina Widya. 2012; 23(3): 135-140.

29. Banjarnahor, S., D., S., \& Artanti, N. Antioxidant Properties of Flavonoid. Med J Indones. 2014; 23(4): 239-244.

30. Radak, M. S., \& Andjelkovic, M. Studying Genotoxic and Anti Mutagenic Effect of Plants Extracts in Drosophila Test System. Botanica Serbica. 2016; 40(1): 22.

31. Farkhan, A., Arijani, E., \& Yuliati. Toksisitas Kandungan Tanin dan Saponin pada Ekstrak Daun Mimba (Azadirachta indica) dengan Menggunakan MTT Assay. Oral Biology Dental Journal. 2012; 4 (2): 28-32.

32. Gunawan, C., Mulawarmanti, D., \& Laihad, F. Sitotoksisitas Ekstrak Daun Avicennia marina terhadap Sel Fibroblas. Dental Jurnal Kedokteran Gigi. 2014; 8(2): 69.

33. Wink. Modern Action of Herbal Medicines and Plant Secondary Metabolites. Journal Medicines. 2015; 2: 251-286. 